\title{
The Usage of Social Media as an Information Seeking Tool of Halal Food Products
}

\author{
Siti Zanariah Yusoff (Corresponding author) \\ Department of Modern Languages and Communication, Faculty of Languages and Communication \\ Universiti Sultan Zainal Abidin, 21300 Kuala Nerus, Terengganu, Malaysia \\ E-mail: zanariahyusoff@unisza.edu.my \\ Nazilah Mohamad \\ Department of Modern Languages and Communication, Faculty of Languages and Communication \\ Universiti Sultan Zainal Abidin, 21300 Kuala Nerus, Terengganu, Malaysia \\ E-mail: nazilahmohamad@unisza.edu.my \\ Mohd Faradi Ghazali \\ Department of Modern Languages and Communication, Faculty of Languages and Communication \\ Universiti Sultan Zainal Abidin, 21300 Kuala Nerus, Terengganu, Malaysia \\ E-mail: faradighazali@unisza.edu.my \\ Nor Hafizah Abdullah \\ Department of Modern Languages and Communication, Faculty of Languages and Communication \\ Universiti Sultan Zainal Abidin, 21300 Kuala Nerus, Terengganu, Malaysia \\ E-mail: hafizahabdullah@unisza.edu.my \\ Sharipah Nur Mursalina Syed Azmy \\ Department of Modern Languages and Communication, Faculty of Languages and Communication \\ Universiti Sultan Zainal Abidin, 21300 Kuala Nerus, Terengganu, Malaysia \\ E-mail: shnurmursalina@unisza.edu.my
}

Received: 10-06-2016

Published: 01-11-2016
Accepted: 20-08-2016

doi:10.7575/aiac.ijalel.v.5n.6p.245
Advance Access Published: September 2016

URL: http://dx.doi.org/10.7575/aiac.ijalel.v.5n.6p.245

\begin{abstract}
The purpose of this paper is to examine the role of social media as an information seeking tool of halal food products among Muslim. This is a conceptual paper which employed a comprehensive review to investigate strategy used by Muslim family in information seeking of halal food products using social media. This study had revealed that respondents are likely to use social media in search for information regarding halal foods. As expected by the researchers, children tend to be the majority users of social networking sites compared to their parents. It is crucial for each Muslim to seek information about halal foods as there are too much dumping information that lead to confusion among consumers. Other than that, this study proved the usage of social media not only limited to entertainment yet it plays a vital part as an information seeking tools as well.
\end{abstract}

Keywords: Information seeking, halal food, social media, Muslim family

\section{Introduction}

Malaysia remains as a leader for global halal hub (State of Global Economic Report, 2015) due to the large potential of halal business and the unique position and strength. The concept of halal refers to the manner of producing goods and services according to shariah compliance. This involves not only food products but also pharmaceutical products and financial practices. The halal food industry is crucial for Muslims all over the world as it serves to ensure that they consume halal daily food. Tremendous growth in this industry shows that Muslim population is rapidly increasing to 2.08 billion on 2014, made the demand for halal food gaining more attention worldwide.

Siti Zanariah, Nor Azura and Jusang (2014) stated that, to prove that halal food is essence to all Muslim, Malaysia plays host to two of the most important annual events in the halal industry, namely the Malaysia International Halal Showcase (MIHAS) and the World Halal Forum (WHF). Both play a pivotal role in building the country's reputation as the global 
reference and trade centre for the new mainstream of halal industry since 2003. With the government's full support and heavy involvements, Malaysia's credibility and leadership in the halal sector is also recognised by the Organisation of Islamic Cooperation (OIC).

In order to generate a better generation with a pure heart, information seeking on halal products is a must. Furthermore, its importance is supported by Abu Hurairah r.a. in a hadith: Anyone who seeks halal things for their family, he is like a man who fights for the cause of Allah. And to those who seek to protect his dignity; he is at the rank of martyrs. (narrated by at-Tabrani). This hadith gives clear meaning about the importance of seeking halal information even though people need to face some obstacles to get them. Basically, halal concept is a simple concept so that Muslim could easily understand it. But, the current scenarios in the industry make it difficult and led to consumer confusion (Khalilah, 2012). All of Muslims understand and have basic knowledge about all of halal foods as long as there is no sentence in Al-Quran or hadith forbid Muslims to eat it.

Based on the research that has been done related to information seeking of halal food products by Siti Zanariah, Nor Azura and Jusang (2014), four factors have been tested in order to identify which factors lead to information search; confusion, awareness, attitude and religiosity. The findings of the research show that people with high level of confusion, high level off awareness, have positive attitude and high level of religiosity have significance relationship with information seeking behavior. They are highly active in seeking information of halal food products.

\section{Halal Issue}

The exposure of halal issue becomes a hot topic debate among society as it is vigorous for religion issue. Report shows that The Islamic Development Department (Jakim) withdrew halal certification from Secret Recipe Manufacturing Sdn. Bhd due to violations involving hygiene offense under the Malaysian Halal Certification Procedure Manual and Good Manufacturing Practice (Astro Awani, 2015). This kind of issue becomes polemic in Muslim society. They have expressed their mixed responses on the matter since the issue has sparked concern among Malaysians, particularly the Muslim community. It can be seen through hot debate in social media, as it provides easier way to publish people thoughts and reach people all over the world (Astro Awani, 2015).

People do search information to fulfill their information needs. With dumping information on halal issue trigger the level of confusion among consumers, such as 'pork free' logo (Hub Halal Division, JAKIM, 2016). According to Datuk Seri Hamzah Zainuddin, minister at Ministry of Domestic Trade, Co-Operatives and Consumerism, 'pork free' or 'no pork' logo lead to confusion among multi ethnics consumers in Malaysia. Consumers are advised to not buy and eat at any premises with this logo. As a consumer, they have to be concern and must review the halal status of the premises they want to dine in as the intention of the seller with the 'pork free' logo is to attract more Muslim consumers (Berita Harian, 2016). This scenario looks like they can't differentiate which premises own the authentic halal logo and which one is not. This paper aims to know how they search for information regarding halal foods using social media as we know social media has variety of functions, not only serves as an entertainment function.

While other studies have examined how Muslims use social media websites (Al-Mutawa, 2013; Mishra and Seeman, 2010) and the use of social media tools to search halal food information in the U.S. (Yusliza et al., 2014). Even though there are quite number of researches have been done in social media context, this paper focuses on the strategy to search information on halal food products. The objectives of this paper are to identify the strategies of information seeking among Muslim family via social media including Facebook, Twitter, Instagram, smartphone's applications, blogs and to examine how they use these media to fulfill their information needs about halal food products.

\section{The Functions of Social Media}

Social media usage is not limited. In fact, it is not surprising that the social media has changed the landscape of people to communicate, from face-to-face communication to Computer Mediated Communication (CMC). Social media has become more than just how people keep in touch with their friends online rather than changing the way people communicate and how they manage their daily lives. Social media is considered as a category of online discourse where people create content, share and bookmark it as well as focusing on creating networks or social relationships among people. These sites basically enable any information-sharing activities such as sharing interests and current issues as well (Saodah Wok et.al 2012). Moreover, online communities may offer a welcoming and comfortable environment (Rashid, A. Rahman and Rahman, 2016) to share and discuss personal experiences with other Social Networking Sites (SNS) users according to their preferences.

According to Bilgihan, Cheng \& Kandampully (2014), Generation Y seeks and shares dining information on SNS at a moderate frequency, though a small proportion of Generation $Y$ exhibits very active information seeking and sharing behavior. These findings highlight the importance of social media marketing, in the sense that companies and restaurants must recognise and exploit the power of social media. Bearing in mind the large number of Generation $\mathrm{Y}$ are using SNS, marketers should open new channels to reach this emerging growth segment. For example, instead of distributing flyers and menus on the streets, restaurants might build Facebook fan pages to connect with diners and post commercials or promotions on SNS. If a restaurant does not offer such online interactions, it could be losing out on a vast number of potential patrons. Restaurants also might create their own SNS to help Generation Y find and engage with them online (Bilgihan,Cheng, \& Kandampully, 2014).

Tulloch and Zinn (2011) explain that media is a medium of communication and the most influential tool in searching information towards present modern society development because media itself can form 'reality' towards society due to its ability to change society's emotion. This because the media do not work individually but the media also assisted by 
the role of communication with that finally produces mass communication concept. Indirectly, through media, society can be exposed with various latest information, regardless of positive or negative.

Social media on the other hand is a channel social contact online in the virtual world (internet). According to Yusup (1997) in Marlini (2008), the internet has now become one of the important innovation in education. Meanwhile, according to William (1995) in Marlini (2008) internet is also a future textbook. Therefore, social media is one of the fast track for Muslim community to look for various information especially information on halal food. This is the best alternative way when there are too many information disorder on halal food product in Malaysia.

A study conducted by Mohd Anuar et.al (2015) entitled 'false spread information related to halal products and implications for the halal industry' discuss false information and spreading medium of halal products as well as effects on the halal industry. This study shows the impact of false spread information not only affects the products but also to consumers, entrepreneurs, and the halal authority. This study uses secondary data from websites, newspapers, books, articles, journals and printed materials to examine the fraud of halal information. As a result, there are four main issues that often falsified information about halal products in the community such as which products contain alcohol, pigs slaughter, and also cleanliness. The source food products frequently become viral in the dissemination of false information of halal products such as noodles, biscuits, chocolate, drinking water and bread. Among the medium that become the dissemination of false information are through social media like Facebook, Instagram, Telegram, Whatsapp etc., SMS and emails, websites and blogs are also as a medium of spreading of halal false information.

\section{Information Seeking}

The definition of information seeking, as stated by Kuhtlau (1991), is a process of goal information oriented, which is individual involves give their effort to get the information from various resources to fulfill their needs. They might find information from the interpersonal approach, organization and mass media as well (Johnson and Meischke, 1993). According to Clarke and James (1967); Chaffee and McLoad, (1976), information seeking can be defined as the individual willingness to expose themselves in certain media contents. To further understanding why information seeking is a purposes process, Mokhros and Aakhus (2002), stated that, it gives an answer to the question, evaluation on a certain situation, problem solving can be classified as information seeking. From writer point of view, information seeking can be said that a process of getting information on certain purposes using any suitable methods to fulfill human needs.

In consumer buying decision, information seeking activity take the second place after a problem has been identified. After that, the consumer will search for the goods and services information that they require, including ask other people, media, and the internet. Having enough information about the things they want to buy will help them in choosing any products they want and to take further action (Amirah, 2012). Information is a vital tool in decision making regarding certain matters. Mokros and Aakhus (2002), observed information seeking as an adaptive process which contributes to the learning process, problem-solving ability and decision-making skills. All of these processes need a lot of information. People search for information to fulfill their desire and needs. Therefore, some of them will stop the searching process once they found the information they need. However, information seeking will be continued as they didn't get their information needs. There are three purposes why people search for information; to build awareness, to make a decision and to plan certain things (Sri Fatimah, 2004). One thing to consider is, information that be found is not necessarily give positive result, the information found can be ignored when it contradicts with someone perception towards certain issues.

\section{Halal Food Products}

Islam is very concerned about the issue of halal food. A food will be categorized as halal when the production of raw materials, material components, additives and processing based on the guidelines set out by legislation (Azilawati et al., 2012). Therefore, it includes the preparation, processing, storage, packaging, handling and transportation that meet Shariah compliance (Jakim, 2012). Generally, Islam requires consuming all foods that are fine and forbid eating the foods that are disgusting and dirty (khabaith). Standards of good nutrition for Muslims expressed as halalan toyyiban as the word of Allah S.W.T says:

"O people, eat of what is in the earth, permissible and good, and do not follow in the footsteps of Satan; indeed, for you he is an open enemy".

(Al-Baqarah: 168)

When a consumer is associated with halal product, halal food concept from the Islamic point of view needs to be emphasized because halal is just not merely means edible products of shariah because it contains prohibited substance but also includes the meaning of 'good' that is clean, pure, safe and quality starts from the source (halalan toyyiban). This includes the provision, manufacture, production until it is served to the consumer. In the course of Sahabat Halal Jakim Facebook (2013), the food is fulfilling the concept of halalan toyyiban if it is free from Islamic banned substances, free from the substances that can cause harm, not filthy and also clean and safe. Cases like halal logo abuse, material fraud or content used in a product and also the management of premises that do not comply with halalan toyyiban standards commonly reported. The existence of such cases may raise questions about the validity of halal (Alias, 2012).

\section{Research Implications}

Information seeking strategies via social media are widely used to help people get any information needed in a fast way. For example, Facebook users can easily access to Sahabat Halal page which provides plenty of information regarding 
the halal issue, especially food and beverages. This page allows users to drop comments on each information posted and if the controversial topic posted, thus, it turns to a hot debate. This situation can be seen when Jakim Hub Halal Division Facebook (2016) share a press release about the halal status of Sushi King on their wall, 242 concern users commented on that almost the whole week since the issue going viral. 1,075 of them share the status on their wall, hence, make the issue the hottest topic for that particular time. Therefore, this paper is intended to look at strategies for searching for halal products information using social media besides providing public openness in answering all speculations and confusions of the community in making effective selection of halal products. Furthermore, this study offers precise and systematic social networking medium in determining the quality of halal products in both domestic and international market.

\section{Conclusion}

The emergence of new media in the 21 st century is considered to be one of the most cutting edge discoveries in the development of virtual technology because all delivery of information can be detected rapidly and effectively, causing it to be a major focus in marketing strategies. Relatively, studies of the use of social media as a strategy in finding information regarding halal food products is not a new thing as it has managed to attract the attention of Muslim and non-Muslim researchers from all over the world who examine the matter from various perspectives. However, studies about the use of social media from the context of halal food is still limited and not given enough attention. In addition to that, it is hoped that this study can provide insights from a different angle and acts as a reference for future research that uses social media as its main scope. Academic-wise, it can also be extended to be more in depth as technology erudition has become a leading medium in every branch of knowledge these days. Moreover, it can yield recognition and quality improvement of local Halal products in the international market while indirectly elevate Malaysia in general and Halal Malaysia Official specifically as a halal products manufacturer in accordance with Sharia-compliant standard.

\section{References}

Alias Azhar, Harlida Abdul Wahab, Nurretina Ahmad Shariff \& Muhammad Hafiz Badarulzaman. (2012). Perlindungan Pengguna Terhadap Produk Makanan Halal: Tinjauan Hukum Dan Undang-Undang Di Malaysia. Prosidings WCIT2012.

Astro Awani (2015). Secret Recipe halal certificate revoked. Retrieved on $19^{\text {th }}$ October 2015 From http://english.astroawani.com/malaysia-news/secret-recipe-halal-certificate-revoked-60809

Amirah Hashim. (2012). Consumer attitude towards food. (Power Point Notes).

Azilawati Azizan, Mazlah Yaacob, Nurkhairizan Khairudin,Nor Liza Saad,Norleha Mohammad.(2012). Kesedaran Terhadap Pemakanan Halal Dalam Kalangan Pelajar Islam Peringkat Sekolah Rendah Di Negeri Perak. Prosiding WCIT2012.

Bilgihan, A.,Cheng, Peng; Kandampully, J. (2014). Generation Y's dining information seeking and sharing behavior on social networking sites: An exploratory study. International Journal of Contemporary Hospitality Management 26.3 349-366.

Hyman HH, Sheatsley PB. (1947). Some reasons why information campaign fail. Public Opin Q. Autumn, 11(3), 41223.

Khalilah Abd Hafiz. (2012). Authentication of Halal Products and Halal Development in Asia. Dalam Prosiding $2^{\text {nd }}$ Global Islamic Marketing Conference. Organized by: The United Arab Emirates University and the International Islamic Marketing Association pada 17-19 Januari 2012.

Mokros, H.B. \& Aakhus, M. (2002). From information seeking behavior to meaning engagement practice. Implications for communication theory and research. Human Communication Research, 28(2), 298-312.

Mohd Anuar Ramli et al. (2015). Penyebaran maklumat palsu berkaitan produk halal dan implikasinya terhadap industri halal. http://eprints.um.edu.my/14517/1/0001.pdf

Marlini. (2008). Penggunaan Intermet dalam Pencarian Maklumat di kalangan Pelajar-pelajar Indonesia di Universiti Malaya. Disertasi untuk Ijazah Sarjana Sains Perputaakn dan Maklumat. Kuala Lumpur: Universiti Malaya.

Rashid, R.A., Rahman, M.F.A., and Rahman, S.B.A. (2016). Teachers' engagement in social support process on a networking site. Journal of Nusantara Studies, 1(1).

Saodah Wok, Syed Arabi Idid \& Norealyna Misman (2012). Social media use for information-sharing activities among youth in Malaysia. Journalism and Mass Communication, 2(1), 1029-1047.

Siti Zakiah Melatu Samsi, Othman Ibrahim, Rahayu Tasnim (2012). Review on knowledge management as a tool for effective traceability system in halal food industry supply chain. Journal of Research And Innovation In Information Systems.1.78-85. http://seminar.utmspace.edu.my/jisri/Volume1.html

Tulloch, J.C. \& Zinn, J.O. (2011). Risk, health and the media. Health, Risk \& Society. 13(1): 1-16.

Yusoff, S. Z., Adzharuddin, N. A., \& Bolong, J. (2014). Faktor pencetus perilaku pencarian maklumat produk halal dalam kalangan keluarga Islam. Global Media Journal Malaysian Edition, 3(2), 69-82. 